\title{
Political changes and trends in cardiovascular risk factors in the Czech Republic, 1985-92
}

\author{
Martin Bobak, Zdenka Skodova, Zbynek Pisa, Rudolf Poledne, Michael Marmot
}

\begin{abstract}
Background-Mortality from cardiovascular diseases is substantially higher in central and eastern Europe than in the west. After the fall of communism, these countries have undergone radical changes in their political, social, and economic environments but little is known about the impact of these changes on health behaviours or risk factors. Data from the Czech Republic, a country whose mortality rates from cardiovascular diseases are among the highest, were analysed in this report.
\end{abstract}

Objectives-To examine the trends in cardiovascular risk factors in Czech population over the last decade during which a major and sudden change of the political and social system occurred in 1989, and whether the trends differed in relation to age and educational group.

Design and setting-Data from three cross sectional surveys conducted in 1985,1988 , and 1992 as a part of the MONICA project were analysed. The surveys examined random samples of men and women aged 25-64 in six Czech districts and measured the following risk factors: smoking, blood pressure, body mass index (BMI), and total and high density lipoprotein (HDL) cholesterol.

Results-The numbers of subjects (response rate) examined were $2573(84 \%)$ in $1985,2769(87 \%)$ in 1988, and $2353(73 \%)$ in 1992. Total cholesterol and body mass index increased between 1985 and 1988 and decreased between 1988 and 1992 . The prevalence of smoking was declining slightly in men between 1985 and 1992 but remained stable in women. There were only small changes in blood pressure. The decline in cholesterol and BMI in 1988-92 may be related to changes in foods consumption after the price deregulation in 1991. An improvement in risk profile was more pronounced in younger age groups, and the declines in cholesterol and obesity were substantially larger in men and women with higher education. By contrast, there was an increase in smoking in women educated only to primary level. Conclusion-Substantial changes in cholesterol, obesity, and women's smoking occurred in the Czech population after the political changes in 1989. Although a causal association cannot be claimed, national trends in foods consumption are consistent with changes in blood lipids and obesity. Further monitoring of trends is required to confirm these trends.

(F Epidemiol Community Health 1997;51:272-277)

Life expectancy in countries of central and eastern Europe (CCEE) is substantially lower than in western Europe. ${ }^{1}$ The gap has largely developed over the last several decades, and most of it is caused by high mortality from cardiovascular diseases (CVD). ${ }^{2}$ It is commonly accepted that life style (high levels of smoking, alcohol consumption, and low physical activity) and diet (high intakes of saturated fats or low intakes of fresh fruit and vegetables) are at least partly responsible for the high mortality. ${ }^{234}$ As the levels of risk factors (as well as rates of CVD) are closely related to socioeconomic factors, the social and political circumstances in these countries probably underlay the postwar trends in mortality pattern in the CCEE.

Since the beginning of the political and economic reforms in 1989, circumstances in the CCEE have changed dramatically and their populations have been exposed to a new social environment. ${ }^{5}$ Available information suggests that several patterns of mortality trends emerged in the post-1989 period in the region, depending on the social impact of the reforms: mortality increased dramatically in the former Soviet Union, previous trends continued in most other CCEE, and decreased in Poland and the former Czechoslovakia. ${ }^{5}$

The Czech Republic has had the highest mortality among industrialised countries and the highest mortality from coronary heart disease in Europe in 1991 (WHO Health for All database). Mortality from all causes (driven by CVD) reached its peak in the mid 1980s and has been declining since, except for an increase in men in 1990 (fig 1). Data from three Czech MONICA surveys in 1985, 1988, and 1992 have provided us with the opportunity to study trends in cardiovascular risk factors over the last decade and to investigate whether different segments of the population are differentially susceptible to the social changes. The data allowed to assess the trends by sex, age, and education.

\section{Methods}

The MONICA project is a WHO coordinated study set up in 38 centres in 26 countries to monitor trends in CVD mortality and risk factors (smoking, cholesterol, blood pressure 
Table 1 Levels of risk factors in 1985, 1988, and 1992 MONICA surveys in the Czech Republic. Men and women 25-64 years old, age standardised.

\begin{tabular}{lllll}
\hline & Sex & 1985 & 1988 & 1992 \\
\hline No of subjects (response rate in \%) & M & $1256(82)$ & $1357(86)$ & $1141(71)$ \\
& F & $1317(85)$ & $1412(88)$ & $1212(75)$ \\
Total cholesterol (mmol/) & M & 6.21 & 6.28 & $5.96^{* * *}$ \\
& F & 6.19 & 6.23 & $5.96^{* * *}$ \\
HDL cholesterol (mmol/) & M & 1.35 & 1.32 & 1.31 \\
& F & 1.57 & 1.56 & $1.51^{* * *}$ \\
HDL/total cholesterol ratio & M & 0.23 & 0.22 & $0.23^{* * *}$ \\
& F & 0.26 & 0.26 & 0.26 \\
BMI $\left(\mathrm{kg} / \mathrm{m}^{2}\right.$ ) & $\mathrm{F}$ & 26.9 & 27.6 & $27.2^{* *}$ \\
Diastolic BP (mm Hg) & $\mathrm{M}$ & 85.8 & 27.6 & $26.8^{* * *}$ \\
Systolic BP (mm Hg) & $\mathrm{F}$ & 82.6 & 84.3 & $86.1^{* * *}$ \\
Smoking prevalence (\%) & $\mathrm{M}$ & 135.6 & 81.4 & $82.6^{* *}$ \\
& $\mathrm{~F}$ & 131.8 & 134.5 & 134.7 \\
& $\mathrm{~F}$ & $45 \%$ & $42 \%$ & 130.5 \\
\hline
\end{tabular}

Statistical significance of differences between 1988 and 1992: ${ }^{*} \mathrm{p}<0.05,{ }^{* *} \mathrm{p}<0.01,{ }^{* * *} \mathrm{p}<0.001$.

and obesity) over a 10 year period. ${ }^{6}$ During this period, each centre conducted three surveys in samples of its study population, and organised a register of myocardial infarctions. In the Czech Republic, the MONICA study was run in six districts, and data collected in these districts in 1985,1988 , and 1992 were used for the present analysis.

For each survey, a new random sample of the population of the selected six districts aged 25-64, stratified for age and sex, was drawn from population register. CVD risk factors were measured by questionnaire, physical examination, and in blood samples, following the MONICA protocol identical in all three surveys. ${ }^{6}$ Participants were classified as current smokers if they currently smoked at least one cigarette daily. Blood pressure was measured twice with a mercury sphygmomanometer in seated subjects after at least five minutes' rest. Manometers scaled by $5 \mathrm{mmHg}$ were used in the first two surveys; because of the preference of digits ending by 5 and 0 , devices scaled by $2 \mathrm{mmHg}$ were used in the last survey. Systolic pressure was recorded as Korotkoff phase I sound and diastolic pressure as the phase V.

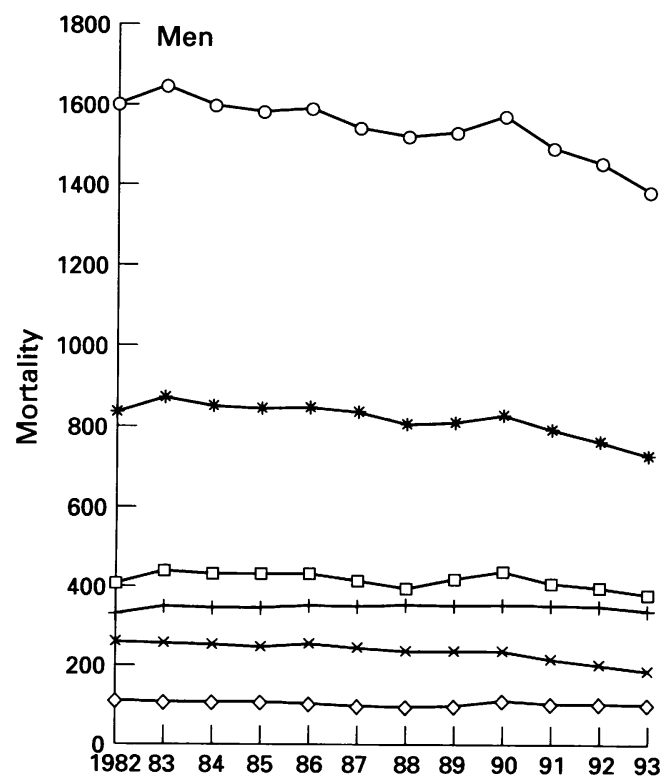

\section{KEY POINTS}

- Mean blood cholesterol and body mass index decreased in the Czech Republic between 1988 and 1992 during a period of profound and sudden political, social, and economic changes.

- The decline in cholesterol was largest in younger and better educated people.

- These changes may reflect an increase in prices of foods, particularly of animal origin, and wider choice of foods such as fruits, vegetables, and vegetable oils.

The mean of the two values was used in these analyses. Height and weight were measured in subjects undressed to underwear and without shoes, and body mass index (BMI) was calculated as weight (in $\mathrm{kg}$ ) divided by square of height (in $\mathrm{m}$ ). Blood samples were taken after overnight fasting, and total and high density lipoprotein (HDL) cholesterol in serum were analysed in the Institute of Clinical and Experimental Medicine in Prague using an enzymatic method (Boehringer Mannheim). All three surveys were conducted in same time of the year by special teams of physicians and nurses centrally trained in the examination procedures.

Mean values for continuous variables were adjusted for age by generalised linear models in $S A S .^{7}$ The prevalence of smoking was standardised for age using the direct method, with the pooled population of all three survey as the standard. Because the change in the social system in 1989 occurred suddenly, the $p$ values are presented for the changes between 1988 and 1992 rather than for trends 1985-92.

\section{Results}

Altogether, 7695 persons were examined in the three surveys. The response rate declined

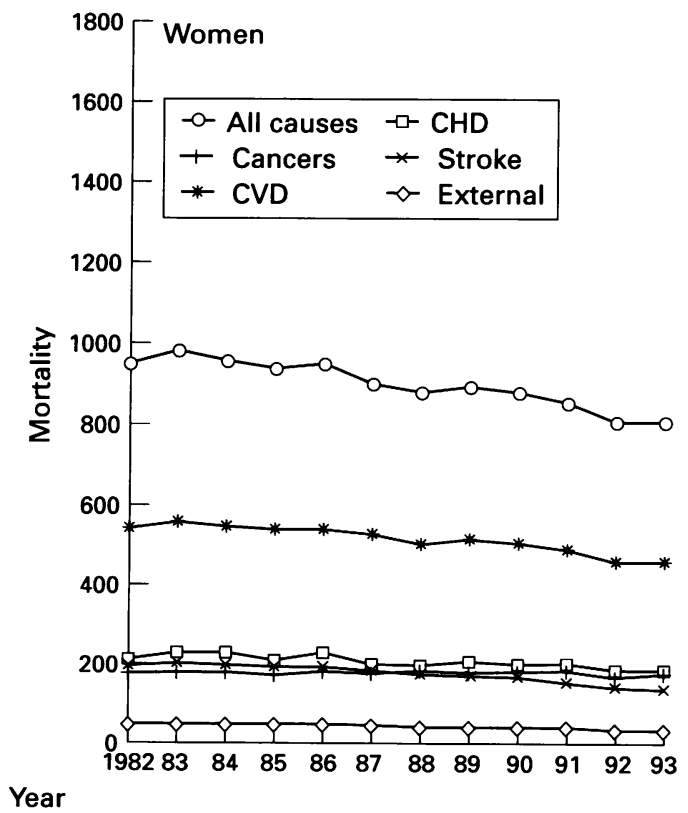

Figure 1 Trends in mortality in the Czech Republic from 1983-93 (all ages, age standardised) for men and women. 
Table 2 Risk factors in relation to age group in the Czech MONICA study 1985-92

\begin{tabular}{|c|c|c|c|c|c|c|c|}
\hline & \multirow{2}{*}{$\begin{array}{l}\text { Age } \\
\text { group } \\
(y)\end{array}$} & \multicolumn{3}{|l|}{ Men } & \multicolumn{3}{|c|}{ Women } \\
\hline & & 1985 & 1988 & 1992 & 1985 & 1988 & 1992 \\
\hline \multirow[t]{3}{*}{ Total cholesterol $(\mathrm{mmol} / \mathrm{l})$} & $25-34$ & 5.72 & $\begin{array}{l}5.87 \\
6.20\end{array}$ & $\begin{array}{l}5.30^{* * *} \\
6.04\end{array}$ & 5.47 & 5.59 & $5.15^{* * *}$ \\
\hline & $\begin{array}{l}35-44 \\
45-54\end{array}$ & $\begin{array}{l}6.34 \\
6.40\end{array}$ & $\begin{array}{l}6.20 \\
6.60\end{array}$ & $\begin{array}{l}6.04 \\
6.34^{*}\end{array}$ & 5.95 & 5.95 & $\begin{array}{l}5.55^{* * * *} \\
627 *\end{array}$ \\
\hline & 55-64 & $\begin{array}{l}0.40 \\
6.39\end{array}$ & 6.44 & $\begin{array}{l}6.34^{*} \\
6.15^{* *}\end{array}$ & $\begin{array}{l}6.55 \\
6.78\end{array}$ & $\begin{array}{l}6.48 \\
6.89\end{array}$ & $\begin{array}{l}6.27^{*} \\
6.87\end{array}$ \\
\hline \multirow[t]{4}{*}{ HDL cholesterol $(\mathrm{mmol} / \mathrm{l})$} & $25-34$ & 1.35 & 1.35 & 1.36 & 1.60 & 1.61 & $1.52^{* *}$ \\
\hline & $35-44$ & 1.35 & 1.32 & 1.31 & 1.55 & 1.54 & 1.52 \\
\hline & $45-54$ & 1.33 & 1.32 & 1.30 & 1.57 & 1.54 & 1.52 \\
\hline & $55-64$ & 1.35 & 1.31 & 1.29 & 1.55 & 1.54 & $1.48^{*}$ \\
\hline \multirow[t]{4}{*}{ HDL/total cholesterol } & 25-34 & 0.25 & 0.24 & $0.27^{* *}$ & 0.30 & 0.30 & 0.30 \\
\hline & $35-44$ & 0.22 & 0.22 & 0.23 & 0.27 & 0.27 & $0.28^{* *}$ \\
\hline & $45-54$ & 0.22 & 0.21 & 0.21 & 0.25 & 0.24 & 0.25 \\
\hline & $55-64$ & 0.22 & 0.21 & 0.22 & 0.24 & 0.23 & $0.22^{*}$ \\
\hline \multirow[t]{3}{*}{ BMI $(\mathrm{kg} / \mathrm{m} 2)$} & $25-34$ & 25.5 & 26.2 & $25.5^{*}$ & 23.6 & 24.3 & $23.6^{*}$ \\
\hline & $\begin{array}{l}35-44 \\
45-54\end{array}$ & $\begin{array}{l}26.7 \\
27.6\end{array}$ & $\begin{array}{l}27.1 \\
28.0\end{array}$ & $\begin{array}{l}26.9 \\
27.8\end{array}$ & $\begin{array}{l}26.4 \\
28.5\end{array}$ & $\begin{array}{l}26.9 \\
28.9\end{array}$ & $\begin{array}{l}25.8^{* *} \\
28.2^{*}\end{array}$ \\
\hline & $55-64$ & 27.9 & 29.0 & 28.6 & 30.1 & 30.4 & $29.6^{*}$ \\
\hline \multirow[t]{3}{*}{ Diastolic BP (mm Hg) } & $25-34$ & 81.3 & 80.0 & 80.8 & 75.1 & 74.5 & 75.3 \\
\hline & $\begin{array}{l}35-44 \\
45-54\end{array}$ & $\begin{array}{l}84.8 \\
88.7\end{array}$ & $\begin{array}{l}82.8 \\
86.5\end{array}$ & $\begin{array}{l}85.0^{* *} \\
89.4^{* *}\end{array}$ & $\begin{array}{l}81.4 \\
85.2\end{array}$ & $\begin{array}{l}79.3 \\
84.4\end{array}$ & $\begin{array}{l}79.0 \\
86.9^{* *}\end{array}$ \\
\hline & $55-64$ & 88.2 & 87.9 & 89.3 & 88.7 & 87.6 & 89.1 \\
\hline \multirow[t]{4}{*}{ Systolic BP (mm Hg) } & $25-34$ & 125.7 & 125.5 & 123.9 & 116.6 & 116.0 & 116.0 \\
\hline & $35-44$ & 129.9 & 128.3 & 128.3 & 126.0 & 124.3 & $121.2^{* *}$ \\
\hline & $45-54$ & 140.1 & 137.7 & 140.5 & 136.0 & 135.8 & 137.2 \\
\hline & & 146.6 & 146.6 & 146.0 & 148.6 & 147.0 & 147.9 \\
\hline \multirow[t]{4}{*}{ Current smoking (\%) } & $25-34$ & 53 & 50 & 45 & 35 & 32 & 31 \\
\hline & $35-44$ & 56 & 49 & 48 & 36 & 34 & 34 \\
\hline & $45-54$ & 41 & 43 & 44 & 18 & 20 & $27^{*}$ \\
\hline & & 36 & 29 & 29 & 10 & 11 & 9 \\
\hline
\end{tabular}

Statistical significance of differences between 1988 and $1992:{ }^{*} \mathrm{p}<0.05,{ }^{* *} \mathrm{p}<0.01,{ }^{* * *} \mathrm{p}<0.001$.

notably in 1992 (76\%) compared with 1988 $(87 \%)$, and was slightly higher in women than in men (table 1). Table 1 also shows age adjusted prevalence or means of blood pressure, total cholesterol, HDL cholesterol, BMI, weight for hight ratio (WHR), and smoking in 1985,1988 , and 1992 . The prevalence of smoking did not change substantially during the study period. There was a small decline in blood pressure between 1985 and 1988 , followed by an increase in diastolic blood pressure in 1992. Total cholesterol increased slightly between 1985 and 1988 and declined afterwards. Between 1988 and 1992, mean total cholesterol decreased by $0.34 \mathrm{mmol} / 1$ in men and by $0.27 \mathrm{mmol} / \mathrm{l}$ in women. Although HDL cholesterol also decreased slightly, the ratio of HDL to total cholesterol increased. These biochemical changes were accompanied by changes body mass index which increased between 1985 and 1988 and fell by 0.4 in men and 0.8 in women between 1988 and 1992 . At the average height of the population, this corresponds to a mean weight loss of $1.2 \mathrm{~kg}$ in men and $2.1 \mathrm{~kg}$ in women. Despite this reduction, the 1992 levels in men were higher than in 1985.

The changes in cholesterol were more pronounced in the youngest age groups (table 2). The decrease in total cholesterol between 1988 and 1992 in men was $0.56 \mathrm{mmol}$ in 25-34 year olds compared with 0.24 in $45-54$ year olds. This contrast was in even larger in women $-0.57 \mathrm{mmol} / 1$ in the age group $25-34$ years compared with $0.01 \mathrm{mmol} / 1$ in those aged 55-64. BMI declined significantly in all age groups in women but only in the youngest men. The decline in smoking in men seemed to be steeper in the youngest age group while the prevalence in the age group 45-54 was increasing in both genders between 1985 and 1992.

Table 3 shows the levels of risk factors in the three surveys in relation to educational group. The fall in total cholesterol between 1988 and 1992 was largest in secondary and university educated subjects and smallest in primary educated persons. In the university educated, cholesterol has been declining since 1985. The decrease in BMI between 1988 and 1992 was largest in secondary school educated men and university educated women. Changes in blood pressure were small in all strata. The prevalence of smoking in men and women with secondary and university education and in primary educated men decreased between 1985 and 1992 but increased in primary school educated women.

\section{Discussion}

Between 1988 and 1992, several changes in cardiovascular risk factors were observed in the Czech population during a period which coincided with major social changes in the country. Blood lipids and obesity declined substantially in both sexes and the prevalence of smoking declined in all men and in women

Table 3 Risk factors in relation to education in the Czech MONICA study 1985-1992, age adjusted means (prevalence of current smoking)

\begin{tabular}{|c|c|c|c|c|c|c|c|}
\hline & \multirow[t]{2}{*}{ Education } & \multicolumn{3}{|l|}{ Men } & \multicolumn{3}{|l|}{ Women } \\
\hline & & 1985 & 1988 & 1992 & 1985 & 1988 & 1992 \\
\hline \multirow[t]{2}{*}{ Total cholesterol $(\mathrm{mmol} / \mathrm{l})$} & Primary & 6.19 & 6.27 & $6.04^{* * *}$ & 6.20 & 6.22 & $6.02^{* * *}$ \\
\hline & Secondary & 6.29 & 6.36 & $5.89^{* * *}$ & 6.16 & 6.33 & $5.89^{* * *}$ \\
\hline \multirow{3}{*}{ HDL cholesterol $(\mathrm{mmol} / \mathrm{l})$} & University & 6.21 & 6.14 & $5.67^{* * *}$ & 6.13 & 5.90 & 5.66 \\
\hline & Primary & 1.36 & 1.33 & 1.33 & 1.54 & 1.53 & $1.50^{*}$ \\
\hline & $\begin{array}{l}\text { Secondary } \\
\text { University }\end{array}$ & 1.32 & 1.30 & 1.29 & 1.60 & 1.59 & $1.52^{*}$ \\
\hline \multirow{3}{*}{ HDL/total cholesterol ratio } & Primary & $\begin{array}{l}1.34 \\
023\end{array}$ & 1.30 & 1.26 & 1.67 & 1.62 & 1.50 \\
\hline & $\begin{array}{l}\text { Primary } \\
\text { Secondary }\end{array}$ & $\begin{array}{l}0.23 \\
0.22\end{array}$ & 0.22 & $0.23^{* *}$ & 0.26 & 0.25 & 0.25 \\
\hline & University & $\begin{array}{l}0.22 \\
0.22\end{array}$ & 0.21 & $0.23^{* *}$ & 0.27 & 0.26 & 0.27 \\
\hline \multirow{3}{*}{ BMI $(\mathrm{kg} / \mathrm{m} 2)$} & Primary & $\begin{array}{l}0.22 \\
27.2\end{array}$ & $\begin{array}{l}0.22 \\
27.7\end{array}$ & 0.23 & 0.28 & 0.28 & 0.28 \\
\hline & Secondary & 26.6 & $\begin{array}{l}27.7 \\
27.5\end{array}$ & & $\begin{array}{l}27.7 \\
26.2\end{array}$ & $\begin{array}{l}28.1 \\
26.5\end{array}$ & $\begin{array}{l}27.5^{*} \\
25.7^{*}\end{array}$ \\
\hline & University & 26.3 & 27.0 & 26.9 & 25.0 & 26.8 & $24.8^{*}$ \\
\hline \multirow{3}{*}{ Diastolic BP (mm Hg) } & Primary & 86.3 & 84.4 & $86.3^{* * *}$ & 83.5 & 81.8 & $83.2^{* *}$ \\
\hline & Secondary & 85.2 & 84.9 & 86.1 & 80.7 & 80.8 & 81.9 \\
\hline & University & 82.8 & 81.7 & $85.5^{* *}$ & 80.2 & 81.6 & 80.8 \\
\hline \multirow[t]{3}{*}{ Systolic BP (mm Hg) } & Primary & 137.1 & 135.5 & 135.7 & 133.3 & 131.1 & 132.0 \\
\hline & Secondary & 133.6 & 133.9 & 133.7 & 127.6 & 130.1 & 128.8 \\
\hline & University & 129.8 & 128.3 & 131.6 & 126.5 & 130.0 & 125.4 \\
\hline \multirow{3}{*}{ Current smoking (\%) } & Primary & 51 & 46 & 46 & 24 & 25 & 30 \\
\hline & Secondary & 41 & 37 & 38 & 24 & 21 & 19 \\
\hline & University & 29 & 27 & 21 & 20 & 12 & 11 \\
\hline
\end{tabular}

Statistical significance of differences between 1988 and $1992:{ }^{*} p<0.05,{ }^{* *} p<0.01,{ }^{* * *} p<0.001$. 


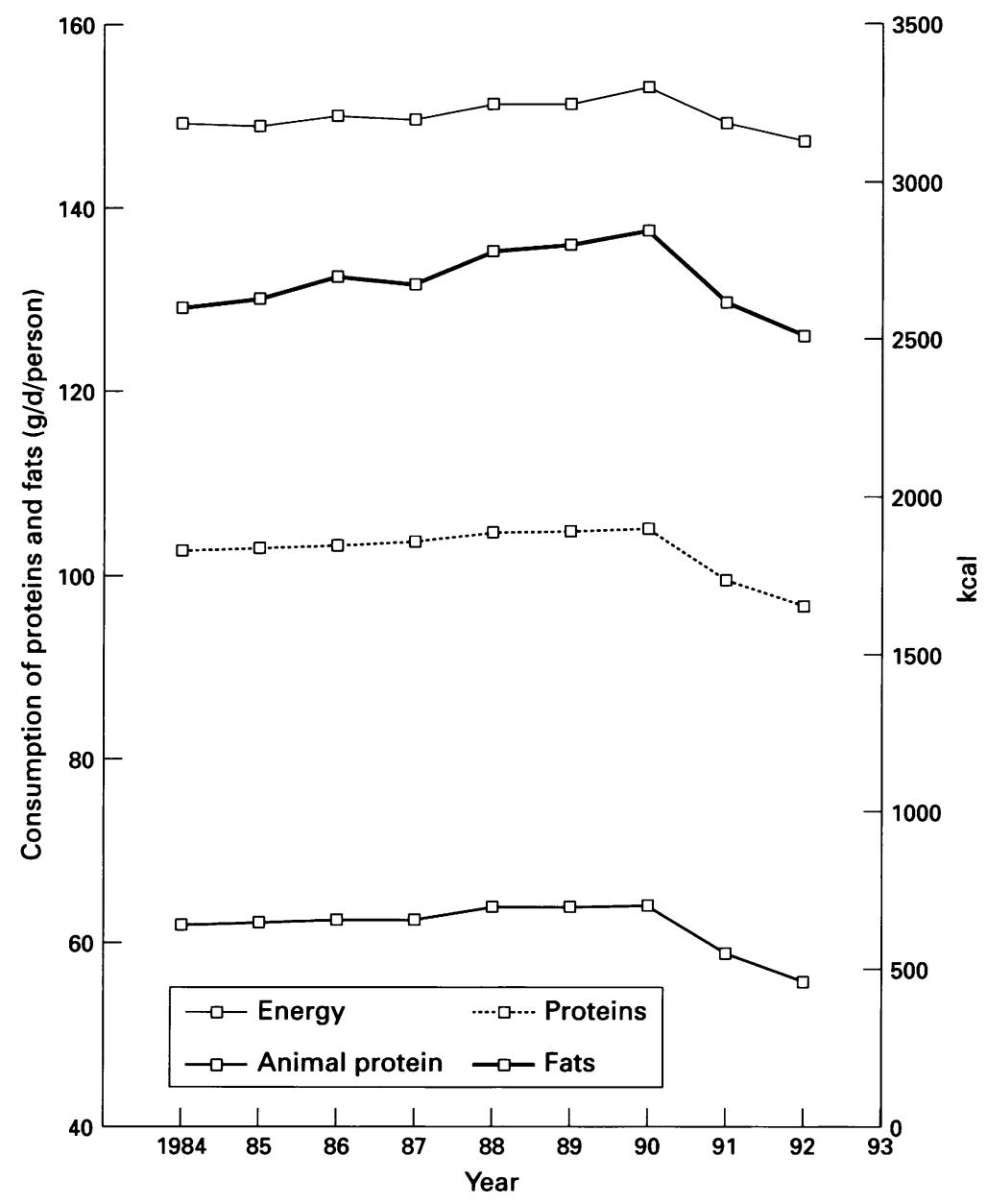

Figure 2 Trends in total energy intake and consumption of proteins and fats in the Czech Republic, 1984-92. non-participants had a lower BMI than participants but this is probably due to underestimation in self reporting.

It is difficult to quantify the extent to which the non-response influenced our findings. Our calculations suggested that the prevalence of smoking in 1992 could have been underestimated by some $4 \%$, but as there were no differences between responders and nonresponders in education and self reported hypertension, the bias in other factors is probably small. Moreover, non-participation in 1992 seemed to be positively related to economic activity: Non-respondents stated that lack of time due to work was the most common reason for not attending the examination. The lowest response rate in 1992 was recorded in two districts on the borders with Austria and Germany. A substantial proportion of the population of these districts commutes to work in Austria and Germany. As economically active persons are probably more fit than the general population, their non-participation would lead to overestimation of the ill health in the sample and thus counterbalance the bias.

It is unlikely that the lower concentrations of blood lipids found in 1992 are due to laboratory bias. First, the laboratory used serves as a WHO MONICA reference laboratory for lipid analysis and is continuously standardised against the Centres for Disease Control, Atlanta. A systematic decrease in readings of the magnitude observed in our study would soon be discovered. Second, the decrease in lipids was not uniformly distributed among the study subjects: it was related to age, sex, and education. Finally, the decrease in blood lipids is consistent with the drop in BMI, where such measurement bias is virtually impossible.

Although the changes between 1988 and 1992 were our primary interest, the period 1985-88 needs to be addressed first. Cholesterol and BMI increased during this period while blood pressure and smoking showed a small and non significant decline. The 1980s, until the 17 November 1989, could best be described as a period of stagnation in terms of social, economic, and political development. There was no apparent increase in disillusionment or a decline in living standards in the Czech Republic. In this context, we tend to see the 1985-88 changes in risk factors as a continuation of previous trends with, possibly, a levelling off of the increase in smoking. Admittedly, the lack of comparable data on risk factors collected before 1984 does not allow more objective conclusions. It has been argued that the decrease in blood pressure in 1988 was due to a hypertension control programme introduced in the MONICA districts after $1985 .^{89}$

In contrast to Hungary or Poland, the change of the political system in the Czech Republic in November 1989 was sudden and, to our knowledge, surprising for most people. Equally sudden were the social and economic measures adopted by the new government, as well as their impact on the everyday life of most people. It has been estimated that the real income of Czech households in 1992 was some $25 \%$ lower 


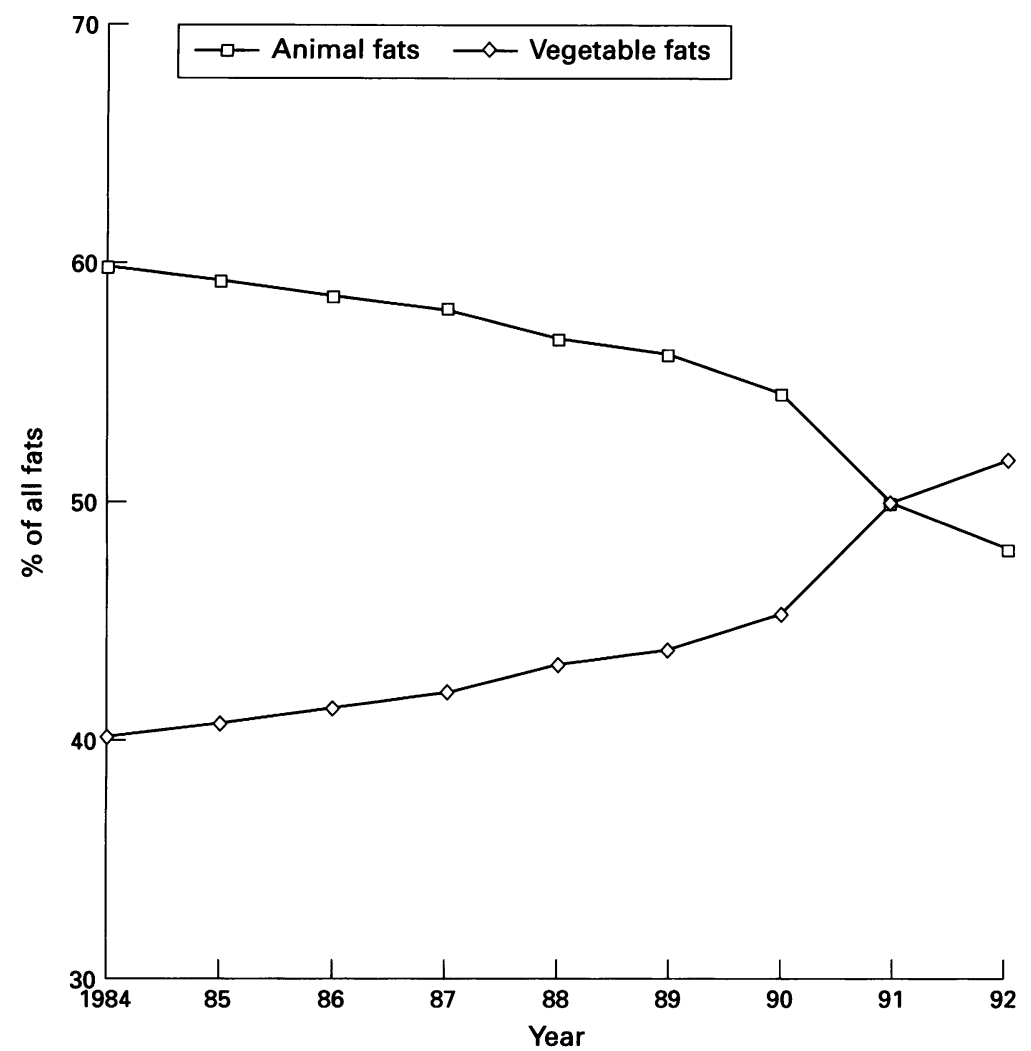

Figure 3 Trends in the per capita consumption of animal and vegetable fats in the Czech Republic, 1984-92. proportion of the population employed in the private sector, and uncertainty about the availability of health services may have made people more aware of their health. Opinion polls conducted since 1990 have repeatedly shown health as the most valued asset. This might also have also contributed to the observed changes in risk factors and diet. Previously unknown job insecurity, despite low unemployment (around 3\%), together with the substantial fall in real wages and less generous social benefits might have also played a role, although one would expect more unfavourable effects of such changes on life style than those found in our data. It has been suggested that the collapse of the hypertension control programme during decentralisation of health services could be related to the small increase in diastolic blood pressure. ${ }^{12}$

The decline in risk factors found in the Czech Republic may be part of a similar trend found in some west European countries, ${ }^{13141516}$ although cholesterol levels did not decline in all populations. ${ }^{1617}$ In Germany, the western country most similar to the Czech Republic, small increases in total cholesterol and BMI were observed between 1984 and 1991, at a time of a $19 \%$ decline in CVD mortality, and available data suggest an even more substantial increase in cholesterol since the early $1970 \mathrm{~s}^{17}$ German trends in smoking, on the other hand, were more similar to those observed in the Czech population in that the changes in men were more favourable then in women. ${ }^{17}$ This also seems to support the possible association between social changes and the subsequent fall in cholesterol and BMI in Czech data.

Only limited knowledge exists on whether similar changes occurred in other CCEE. Intake of fats, cholesterol, and total energy decreased in Warsaw where the social changes affected the population in a similar way but blood lipids did not decline (Professor Rywik, personal communication). Total cholesterol further increased in the rural area of Tarnobrzeg, Poland, where the majority of the population were farmers who supplied their own food (Dr Pajak, personal communication). Both Polish MONICA centres observed an increase in smoking, particularly in subjects with low education. In the former East Germany, a small increase in the total caloric intake was observed after unification, with a shift of caloric intake from fats to carbohydrates ${ }^{18}$ and an increase in vitamins intake. ${ }^{19}$ On the other hand, there was no improvement in risk factors after the unification, and prevalence of smoking and mean levels of blood pressure and cholesterol (in women) increased in younger age groups. ${ }^{20}$ This may be related to the fact that the political changes made, at least initially, the East German population relatively more affluent and did not limit their spending on food. In general, observations from other CCEE are consistent with the important role of social conditions and economic incentives for changes in risk factors observed at population level.

The trends in educational differentials in risk factors are also important. In 1992, there was 
a gradient in all risk factors in both genders, with the most unfavourable levels in the lowest educational group. In the case of cholesterol, the gradient has developed over the last five years, as did the differences in smoking among women. This suggests that the socioeconomic differences, serum cholesterol and smoking increased but the educational gradient in other risk factors generally persisted over the observed period. Apart from smoking in women, these differences do not seem to be caused by deterioration in the less educated but rather by a more rapid improvement in the better educated. Our data suggest that younger people and those with better education are more susceptible to change in the desired direction.

The changes in cholesterol and obesity observed between 1988 and 1992 are not unimportant. They are as big as or bigger than can be achieved by individual health counselling. ${ }^{21}$ It has been estimated that a long term reduction in serum cholesterol of $0.3 \mathrm{mmol} / 1$ (observed in our data) can lead to some 15\% drop in mortality from coronary heart disease. ${ }^{22}$ This shows the potential value of intervening at a societal level. On the other hand, it is not clear how these trends in risk factors relate to trends in mortality observed over the last decade. Cholesterol and obesity started to improve after 1988, while mortality decline started during the $1980 \mathrm{~s}$, before this improvement. (Trends in the MONICA districts are similar to those in the whole Czech Republic shown in fig 1). A similar dissociation between trends in CVD mortality and risk factors was also observed in Germany. ${ }^{17}$ Our data covered a relatively short time period and it is difficult to establish the exact chronology and to attribute the mortality trends to trends in risk factors.

In conclusion, we found substantial changes in cholesterol, obesity, and women's smoking in the Czech population after 1989 which are consistent with national data on foods consumption. These trends seem to be related to the political and consequently social and economic changes after the collapse of communism but, because of the lack of more specific data over a longer period, the role of long term secular trends or other influences cannot the excluded. Whether these changes will be permanent and whether they will have any further effect on declining mortality remains to be seen
We are grateful to our collaborators in the districts for help in data collection and Miroslav Paclt for data management.

Funding: the MONICA surveys were funded by the Czech Ministry of Health. MB is supported by the Wellcome Trust Fellowship in Clinical Epidemiology.

Conflicts of interest: none.

1 Feachem R. Health decline in eastern Europe. Nature 1994; 367:313-14.

2 Bobak M, Marmot M. East-west mortality divide and its potential explanations: proposed research agenda. $B M \mathcal{F}$ 1996;312:421-25.

3 Peto R, Lopez AD, Boreham J, Thun M, Heath CJ. Mortality from tobacco in developed countries: indirect estality from tobacco in developed countries: indirect estimation

4 Kesteloot H. Nutrition and health. Eur Heart $\mathcal{f}$ 1992;13: 120-28.

5 United Nations Children's Fund. Crisis in mortality, health and nutrition. Central and eastern Europe in transition. Public policy and social conditions. Regional Monitoring Report No 2. Florence: UNICEF, 1994.

6 World Health Organization. Multinational monitoring of trends and determinants of cardiovascular diseases - "MONICA Project". Manual of operations. Version 1.1. CVD/MNC. December 1986. Geneva: World Health Organization, 1987.

7 SAS Institute Inc. SAS/STAT User's Guide. Release 6.03 Edition. Cary, NC: SAS Institute Inc. 1988.

8 Pisa Z, Skodova Z, Cicha Z, et al. Blood pressure and hypertension control in Czech population. (In Czech). Pyakt Lek 1989;69:213-16.

9 Skodova Z, Pisa Z, Wiesner E, et al. Vyvoj rizikoveho profilu populace sesti okresu CR. (Trends in risk factor profile in population of six district of the Czech Republic.) (In in population of six district of the

$10 \mathrm{Krejci}$ J, Stikova O. Vyvoj zmen ve spotrebitelske poptavce po potravinach. (Trends in consumers demand for foods). Prague, Vyzkumny ustav zemedelske ekonomiky, 1994.

11 Stikova O, Sekavova H, Mrhalkova I, et al. Spotreba potravin a predikce vyvoje poptavky po potravinarskem zbozi. (Food consumption and prediction of development of demand for foods). Praha, Vyzkumny ustav zemedelske ekonomiky, 1994.

12 Skodova Z, Pisa Z, Pikhartova J, et al. Development of the cardiovascular risk in the population of the Czech Republic. Cor Vasa 1993;35:178-82.

13 Vartiainen E, Puska $P$, Jousilahti $P$, Korhonen HJ, Tuomilehto J, Nissinen A. Twenty-year trends in coronary risk factors in North Karelia and in other areas of Finland. Int $f$ Epidemiol 1994;23:495-504.

14 Sjol A, Grunnet K, Schroll M. Secular trends in serum cholesterol, high density lipoproteins and triglycerides 964-187. Int f Epidemiol 1991;20:105-13.

15 Sigfusson N, Sigvaldason H, Steingrimsdottir L, et al. Decline in ischaemic heart disease in Iceland and change in risk factor levels. $B M F$ 1991;302:1371-75.

16 Menotti A, Scanga $M$, and the responsible investigators. Trends in coronary risk factors in Italy. Int $\mathcal{F}$ Epidemiol 1992;21:883-92.

17 Hoffmeister H, Mensink GBM, Stolzenber H. National trends in risk factors for cardiovascular disease in Germany. Prev Med 1994;23:197-205.

18 Thiel C, Heinemann L, Thai DM. Dietary trends in East Germay: a comparison of the caloric and macronutrient intake before and after the unification. CVD Epidemiology Newsletter 1993;48:74-75.

19 Thiel C, Heinemann L, Minh Thai D, Classen E. Vitamins and minerals in the East German population before and after "the change". CVD Epidemiology Newsletter 1993;48 71-72.

20 Heinemann L, Barth W, Hoffmeister H. Trend of cardiovascular risk factors in the East German population 1968 1992. F Clin Epidemiol 1995;48:787-95.

21 Family Heart Study Group. Randomised controlled trial evaluating cardiovascular screening and intervention in general practice: principal results of British family heart study. BMF 1994;308:313-20.

22 Law MR, Wald NJ, Thompson SG. By how much and how quickly does reduction in serum cholesterol concentration lower risk of ischaemic heart disease? $B M \mathcal{F} 1994 ; 308$ : 367-73. 